\title{
Growth, Development, and Mineral Nutrient Accumulation and Distribution in Tulip from Planting through Postanthesis Shoot Senescence
}

\author{
Carl E. Niedziela Jr., ${ }^{1}$ Paul V. Nelson, ${ }^{2}$ and David A. Dickey ${ }^{3}$ \\ ${ }^{1}$ Department of Biology, Elon University, Elon, NC 27244, USA \\ ${ }^{2}$ Department of Horticultural Science, North Carolina State University, Raleigh, NC 27695-7609, USA \\ ${ }^{3}$ Department of Statistics, North Carolina State University, Raleigh, NC 29695-8203, USA \\ Correspondence should be addressed to Carl E. Niedziela Jr.; cniedziela@elon.edu
}

Received 2 June 2015; Accepted 28 June 2015

Academic Editor: Sowbiya Muneer

Copyright ( 92015 Carl E. Niedziela Jr. et al. This is an open access article distributed under the Creative Commons Attribution License, which permits unrestricted use, distribution, and reproduction in any medium, provided the original work is properly cited.

\begin{abstract}
Tulips were grown under field conditions from mid-November through early-June. Plants were harvested and dissected into eight organs on twenty-one dates. These parts were dried, weighed, and analyzed for $\mathrm{N}, \mathrm{P}, \mathrm{K}, \mathrm{Ca}$, and Mg. A transition (as determined by curve join points) from a linear to a steep negative cubic response occurred prior to shoot emergence for N (82 days after planting (DAP)), at shoot emergence for K (93 DAP) and Ca (94 DAP), and after shoot emergence for Mg (102 DAP) and dry matter (118 DAP). A transition from a linear to a steeper linear response occurred at shoot emergence for P (93 DAP). Growth, organ development, and nutrient accumulation occurred continuously from planting to maturity (188 DAP), except for K which did not accumulate during the initial linear phase. Since the increase in accumulation of all five nutrients preceded the dry matter accumulation, these nutrients could be used as predictors in growth models. Practical implications from this study include the importance of maintaining soil Ca levels through liming and applying the $\mathrm{N}, \mathrm{P}$, and $\mathrm{Mg}$ as split applications with smaller rates at planting and larger rates at emergence. The entire K application may be applied at emergence.
\end{abstract}

\section{Introduction}

Garden tulips (Tulipa gesneriana L.) are geophytes that produce bulbs with an annual renewal and are composed of two to six concentric fleshy scales attached to a basal plate and enclosed in a tunic $[1,2]$. Roots are produced on the surface of the basal plate. The tunic is a very thin, papery external scale. Buds located at the inner bases of the fleshy scales give rise to the organs of the mother plant. The apical bud gives rise to the aerial organs (leaves, scape, and flower) and the lateral buds give rise to daughter-bulbs. The innermost daughter-bulb (A-bulb) is the oldest and largest [3]. From the A-bulb outward, daughter-bulbs become progressively smaller and are designated alphabetically (A, B, C, etc.), with the exception of the outermost bulb which is designated as the H-bulb (H for Dutch huid meaning "skin" or "tunic"). Late in development, the H-bulb grows larger than some of the daughter-bulbs when food reserves from the outermost scale are transferred to this outermost bulb as the scale dries to become the tunic. A schematic of the replacement cycle is presented by De Hertogh et al. [4].

In flowering tulip bulbs, three to five leaves are produced on a scape bearing a terminal flower [1]. Although some cultivars and species can produce more than one flower per scape, most produce only one flower per scape. The annual replacement cycle of the tulip bulb can be divided into three phases. (1) Root growth occurs rapidly following planting in the autumn. The apical bud, which has already differentiated into aerial organs, slowly elongates throughout the winter. (2) In the spring, as temperatures rise, plant growth accelerates. The scape and flower bud rapidly elongate culminating in flowering. The transformation of the vegetative buds (daughter-bulbs) into the next generation of mother-bulbs is initiated and increases after flowering. At the same time, the original mother-bulb scales desiccate. (3) Near the end of spring, the aerial organs and roots senesce and daughter-bulb 
growth ceases. However, in the summer, bud differentiation (vegetative and floral) occurs within former daughter-, now mother-bulbs. Bulbs must reach a critical size (weight) before a flower bud can be initiated. Although the critical size varies by genotype, the minimum size is usually six to eight grams. This range corresponds to approximately six to nine centimeters in circumference $[2,5,6]$.

If tulip bulb growers and gardeners are concerned with annual growth cycles, it has to be noticed that the botanical life cycle of a tulip bulb can span 29 to 41 months $[7,8]$. Normally, the life cycle begins in February in the northern hemisphere with the initiation of a granddaughter-bulb between scales within a daughter-bulb [2]. The daughter-bulb is, in turn, enclosed between the scales within a mother-bulb. During the next 4 months, after the mother-bulb has flowered and senesced, the daughter-bulbs which have now matured to second generation mother-bulbs are lifted. The original granddaughter-bulbs have matured to second generation daughter-bulbs and are contained within the newly formed second generation mother-bulbs. In the succeeding autumn, the new mother-bulbs are planted. If they are of sufficient size by the following spring, they will flower and senesce, and the second generation daughter-bulbs within them will mature to third generation mother-bulbs. Approximately 29 months were required from initiation of the granddaughter-bulbs to maturation into mother-bulbs. If, conversely, daughterbulbs dug at the end of the second summer are too small to flower that next year, they will require an additional year of growth before they reach flowering size for a complete life cycle of about 41 months. The duration of that period is affected by internal factors (bud position inside the bulb) and environmental factors, with fertilization being an important one.

Nitrogen $(\mathrm{N})$ fertilization of tulips is usually divided between autumn and spring applications [9-11]. Small but measurable $\mathrm{N}$ uptake occurs from planting through winter [11-13]. Nitrogen is translocated from the mother-bulb to the shoot [13] and the roots (Benschop, unpublished data). Only trace levels of $\mathrm{NO}_{3}{ }^{-}-\mathrm{N}$ are detectable in the roots. However, Ohyama et al. [14, 15] observed that tulips grown hydroponically in a complete nutrient solution in a glasshouse under natural conditions accumulated large quantities of $\mathrm{N}$ during the winter. It was used later during sprout growth. Following shoot emergence in the spring, an acute increase in $\mathrm{N}$ uptake occurs and continues until the shoot (scape) reaches its maximum height [13, 16, 17]. Nitrogen is usually applied as $\mathrm{NO}_{3}{ }^{-}$shortly after emergence to take advantage of the increased uptake $[12,16,18]$. van der Boon [19] correlated the increased uptake with increases in air temperature and transpiration. Ohyama et al. [14] suggested that $\mathrm{N}$ absorbed by the roots is converted to $\lambda$ methylene-glutamine for transport to other organs during flowering. It was also suggested that $\mathrm{N}$ accumulation in the roots in the winter supplements the $\mathrm{N}$ originally stored in the mother-bulb [15]. Tsutsui [20] stated that additional $\mathrm{N}$ can be applied following flowering to promote the growth of daughter-bulbs. However, this is generally not recommended because the presence of $\mathrm{N}$ under warm soil conditions tends to stimulate the development of Fusarium spp. and this fungal disease is a major cause of bulb loss [1].

Phosphorous $(\mathrm{P})$ and potassium $(\mathrm{K})$ fertilization have been studied less than $\mathrm{N}$ fertilization of the tulip [1]. Smaller leaves [21] and daughter-bulbs that weigh less [22, 23] have been reported as symptoms of $\mathrm{P}$ deficiency. Although flower size appears to be unaffected by different sources of $\mathrm{P}$ [24], flowering could be delayed [25]. van der Boon [19] reported that the tulip bulb shows little or no response to $\mathrm{K}$ fertilizers. Potassium fertilizer applications are decreased in some regions of the Netherlands to reduce the chance of causing magnesium (Mg) deficiency [19]. Interactions between $\mathrm{N}$ and $\mathrm{K}$ have been observed [24, 26]. Tissot [24] reported a synergistic effect on the uptake of both elements when applied at high levels.

Forcing tulip bulbs without a calcium (Ca) fertilizer can result in deficiency symptoms including stem topple, light green foliage, stunting of leaves and scape, and flower bud abortion [27-32]. Fertilization with Ca during forcing has been shown to completely or partially prevent these deficiency symptoms $[1,33-35]$. Fertilizing with $\mathrm{Mg}$ salts can increase the yield of tulips [26]. However, when Mg was applied on a sandy soil with cow manure, it had minimal effects on yield [19]. One or two applications of $\mathrm{MgCl}_{2}$ may be applied after flowering [36]. Mügge and Richter [37] reported that yield was increased with $\mathrm{MgSO}_{4}$ applied either as a spray just after deflowering or as a preplant bulb dip when the soil $\mathrm{Mg}$ concentration was below $30 \mathrm{ppm}$. However, the effects on foliage color and bulb yield are minimal.

Bakker [38] estimated the total kilograms per hectare of $\mathrm{N}, \mathrm{P}, \mathrm{K}$, and Ca used for bulb production as 140 to 150,40 to 50,140 to 150 , and 110 to 120 , respectively. Khan et al. [39] found a combined application of N, P, K, and Zn at $75,50,50$, and $5 \mathrm{~kg} \cdot \mathrm{ha}^{-1}$, respectively, had the best growth, flower quality, and bulb production in tulips under polyhouse conditions.

Several studies followed the accumulation and distribution of biomass and nutrient resources to plant parts in various geophytes throughout the growing season including three cormous perennials (Ixia flexuosa [40], Gladiolus caryophyllaceus [41], and Sparaxis grandiflora subspecies fimbriata [42]), the tuberous Jerusalem artichoke (Helianthus tuberosus) [43], and the bulbous red squill (Urginea maritima) [44]. Subramanian et al. [45] studied the dry matter and nutrient distribution within potato (Solanum tuberosum) tubers at harvest. However, the measurements on potato were taken on only one date and did not include analysis of roots or shoots since harvest for food usually occurs following the senescence of these plant parts.

Fundamental knowledge of when biomass and nutrients are accumulated by a tulip and how resources are allocated within the plant is useful for understanding how these processes impact growth and development. Additionally, this information could be used to develop more efficient and ecofriendly fertilizer management plans for commercial bulb production and landscape-use. The objective of the current study was to determine the relationships among growth, development, and nutrient accumulation and distribution from planting through postanthesis senescence in tulips. 


\section{Materials and Methods}

2.1. Field Preparation. This experiment was conducted at the North Carolina State University (NCSU) Horticulture Field Laboratory in Raleigh, NC $\left(35^{\circ} 47^{\prime} \mathrm{N}\right.$ latitude and $78^{\circ} 42^{\prime} \mathrm{W}$ longitude at an elevation of approximately $121.9 \mathrm{~m}$ above sea level), in a fine, kaolinitic, and thermic Typic Kanhapludult (Cecil series) soil. A sod field was sprayed with the herbicide glyphosate at $0.17 \mathrm{~g} \cdot \mathrm{m}^{-2}$ acid equivalent in earlyOctober 1981. Two weeks later, the field was rototilled using a tractor-mounted rototiller and methyl bromide was applied at $98 \mathrm{~g} \cdot \mathrm{m}^{-2}$. On 17 Nov., a $13 \mathrm{~cm}$ deep layer of composted pine bark ( $\leq 1.3 \mathrm{~cm}$ in diameter) was spread over the site along with hydrated lime and agricultural dolomitic limestone at 2.9 and $1 \mathrm{~kg} \cdot \mathrm{m}^{-2}$, respectively. These amendments were incorporated with the tractor-mounted rototiller to a depth of $28 \mathrm{~cm}$. The final soil $\mathrm{pH}$ was 6.3. A tractor-mounted bed-former was then used to form a bed that was $20 \mathrm{~cm}$ high and $66 \mathrm{~cm}$ wide at the top.

Fritted trace elements (Frit-F-555HF, Pro-Sol Division, Frit Industries, Inc., Ozark, AL 36361), superphosphate (8.8\% $\mathrm{P})$, ammonium nitrate $(34 \% \mathrm{~N})$, and dibasic potassium sulfate $(45 \% \mathrm{~K})$ at $9.15,250,82.5$, and $34 \mathrm{~g} \cdot \mathrm{m}^{-2}$, respectively, were broadcast on the tops of the beds and incorporated using a walk-behind rototiller to $15 \mathrm{~cm}$ deep.

2.2. Planting and Postplant Fertilization. On 17 Nov., bulbs $12 \mathrm{~cm}$ and larger in circumference of Tulipa gesneriana "Paul Richter" were planted $15 \mathrm{~cm}$ deep to the base of the bulb. Five bulbs were spaced $10 \mathrm{~cm}$ apart across the bed with $30 \mathrm{~cm}$ between cross-bed rows. Following planting, beds were covered with a $5 \mathrm{~cm}$ deep layer of pine needles. Prior to planting, five randomly selected bulbs were analyzed separately as whole bulbs for mineral nutrients. The mean macronutrient concentrations in $\mathrm{mg} \cdot \mathrm{g}^{-1}$ dry matter were $14.20 \mathrm{~N}, 1.52 \mathrm{P}$, $8.84 \mathrm{~K}, 0.35 \mathrm{Ca}$, and $0.66 \mathrm{Mg}$. The mean micronutrient concentrations in $\mu \mathrm{g} \cdot \mathrm{g}^{-1}$ dry matter were $12.4 \mathrm{Fe}, 4.3 \mathrm{Mn}, 14.2$ $\mathrm{Zn}$, and $3.4 \mathrm{Cu}$. Following shoot emergence, beds were topdressed with ammonium nitrate and potassium sulfate at 82.5 and $34 \mathrm{~g} \cdot \mathrm{m}^{-2}$, respectively, on $22 \mathrm{Feb}$. (97 days after planting (DAP)).

Natural rainfall was the only source of irrigation throughout the experiment. The planting area for this experiment was surrounded on all four sides by other tulip research plots which served as border rows.

2.3. Harvest. On the day of planting (17 Nov.), three groups of five bulbs each were selected for dissection, weight, and analysis. On twenty harvest dates starting on 25 Nov. and ending on 3 Jun., five plants were dug up from each of the three blocks. Each plant was dissected into eight component parts: roots, scales, basal plate, daughter-bulb, H-bulb, leaves, scape, and flower. The parts were dried at $70^{\circ} \mathrm{C}$ to constant weight, weighed, and analyzed for nutrient content. The rootto-shoot dry matter ratio was calculated by dividing the dry root weight by the sum of leaf, scape, and flower weights. In this study, the shoot was defined as all the aerial structures (those organs which have most of their mass above ground at maturity).
2.4. Tissue Analysis. Tissue was washed in $0.2 \mathrm{M}$ hydrochloric acid $(\mathrm{HCl})$ for 30 seconds, rinsed in deionized water, dried for 24 hours at $70^{\circ} \mathrm{C}$, and then ground to $1 \mathrm{~mm}$ particle size in a stainless steel Wiley Laboratory Mill Model 4 (Thomas Scientific, Philadelphia). A $100 \mathrm{mg}$ subsample was analyzed for total N using a Kjeldahl procedure [46]. A $500 \mathrm{mg}$ subsample of tissue was analyzed for the remaining nutrients by dryashing at $500^{\circ} \mathrm{C}$. After addition of $6 \mathrm{M} \mathrm{HCl}$, the ash was heated to dryness at $100^{\circ} \mathrm{C}$ to dehydrate it and then dissolved in $0.5 \mathrm{M}$ $\mathrm{HCl}$. Phosphate-P was determined by colorimetric analyses [47] using a Model Lambda 3 UV/VIS spectrophotometer (Perkin-Elmer, Norwalk, CT, USA). Potassium, $\mathrm{Ca}$, and $\mathrm{Mg}$ were analyzed using an atomic absorption spectrometer AAnalyst 100 (Perkin-Elmer).

2.5. Experimental Design and Statistical Analysis. The experimental design was a randomized complete block with plants from twenty-one harvest dates randomized in three replicated blocks (63 experimental units). The experimental plot consisted of a single bed divided into three blocks with 120 bulbs planted in each block. The bulbs were arranged within each block in a pattern of 24 cross bed rows of five bulbs each. The experimental unit consisted of one row of five plants. The 21 harvest dates occurred during a 198-day period. Five unplanted bulbs were randomly harvested for the first harvest date on 17 Nov. The four additional rows planted in each plot were used if there was plant mortality in a specific row during the experiment. Means and standard errors were calculated using SAS 9.3 (SAS Inst., Cary, NC) with PROC MEANS. PROC NLIN in SAS used the Gauss-Newton algorithm to fit a nonlinear response curve for total plant response over time for various dependent variables. Join points were estimated as described by Gallant and Fuller [48].

\section{Results}

3.1. Environmental Conditions. The maximum and minimum daily air temperatures and total daily precipitation measured at $2 \mathrm{~m}$ above ground level from planting through final harvest for Raleigh, NC, were provided by the State Climate Office of North Carolina, NCSU, Raleigh, NC (Figure 1). The weather station was located on the campus of NCSU at $35^{\circ} 48^{\prime} \mathrm{N}$ latitude, $78^{\circ} 42^{\prime} \mathrm{W}$ longitude, and an elevation of $121.9 \mathrm{~m}$ above sea level. The lowest temperature was $-16.1^{\circ} \mathrm{C}$ recorded on 11 Jan. (55 DAP). The highest temperature was $33.3^{\circ} \mathrm{C}$ recorded on both 14 and 15 May (178 and 179 DAP, resp.). The total precipitation for the dates included in this experiment was $68.2 \mathrm{~cm}$ for a mean daily precipitation rate of $0.34 \mathrm{~cm}$ per day.

3.2. Growth. Important events in the growth period of 198 days included (1) planting of mother-bulbs on 17 Nov. (0 DAP), (2) shoot emergence on 19 Feb. (94 DAP), (3) minimum plant dry matter measured on 12 Mar. (115 DAP), (4) the first anthesis on 26 Mar. (129 DAP), (5) fifty percent of the plants in bloom on 31 Mar. (134 DAP), (6) peak shoot dry matter on 13 Apr. (147 DAP), (7) maturity beginning of shoot necrosis was on 24 May (188 DAP), and 


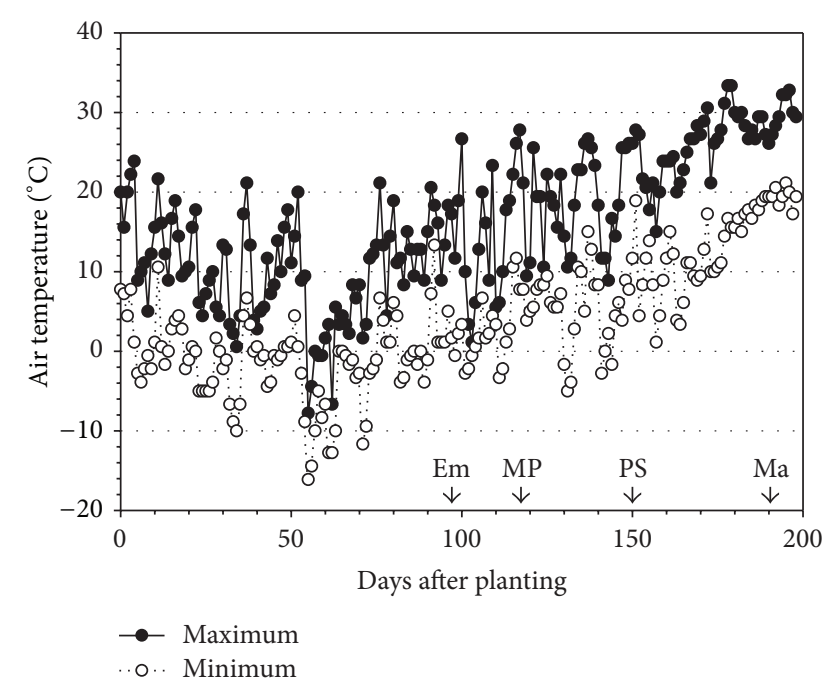

(a)

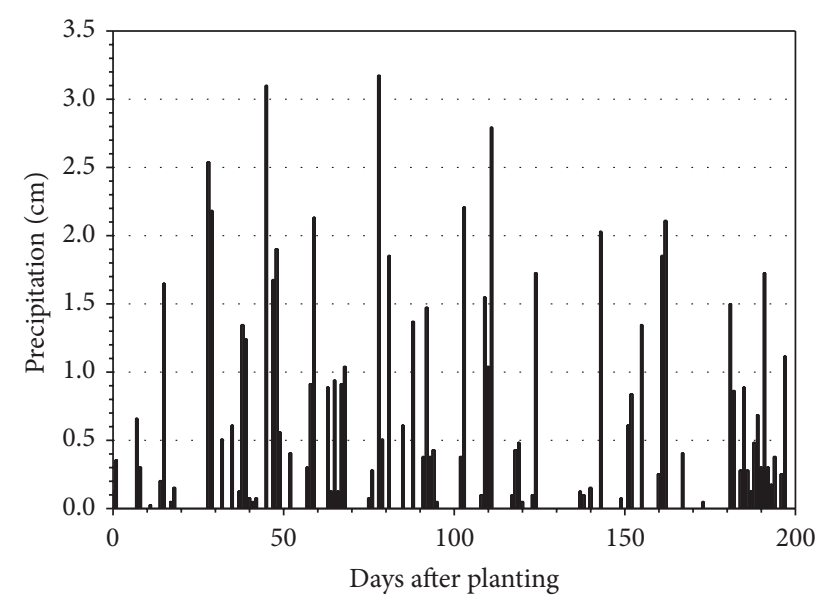

(b)

FIGURE 1: Maximum and minimum daily air temperatures and total daily precipitation measured at $2 \mathrm{~m}$ elevation from planting to the final harvest for Raleigh, NC. The arrows indicate the dates of shoot emergence (Em), minimum plant (MP) dry matter, peak shoot (PS) dry matter, and bulb maturity $(\mathrm{Ma})$.

(8) plants completely straw-colored on 3 Jun. (198 DAP) (Figure 2(a)). At all times from planting to maturity, growth, and development of one or more organs occurred. (The dry matter and nutrient content data presented in Figure 2 are also presented for more accurate quantification in Tables S.1-S.6 of the Supplementary Material available online at http://dx.doi.org/10.1155/2015/341287.)

From planting to minimum plant dry matter, the whole plant dry matter diminished (Figure 2(a)). The major loss was due to declining scale dry matter. This was anticipated due to respiration. Between minimum plant dry matter and peak shoot dry matter (leaves, scape, and flower), plant dry matter increased at a continually increasing rate. During this period, dry matter of shoots, the H-bulb, and daughterbulbs increased while scales continued to decrease as their content was reallocated to the cited organs. Between peak shoot dry matter and maturity (188 DAP) plant dry matter continued to increase, but at a declining rate. Loss in scale and shoot dry matter during this period was more than offset by the gain in H-bulb and daughter-bulb dry matter. After maturity, total plant dry matter declined due to losses in all organs.

Roots appeared by 17 DAP, grew to a maximum dry matter of $0.573 \mathrm{~g}$ per plant by $167 \mathrm{DAP}$, and then decreased to $0.29 \mathrm{~g}$ at $198 \mathrm{DAP}$ (Figure 2(a)). Shoot dry matter increased from planting to 147 DAP. During the first 43 days, root growth outpaced shoot growth resulting in an increase in root-to-shoot ratio from 0 at planting to 0.69 at 43 DAP (Figure 3). Beyond 43 DAP, root growth slowed as it approached maximum size while shoot growth continued to increase, particularly after emergence. During this period, the root-to-shoot ratio declined to 0.05 . Then, the root-to-shoot ratio increased to 0.13 in the post-shoot-peak period as shoot dry matter declined faster than root dry matter.

The shoot grew continually from planting and reached maximum dry matter at 147 DAP (Figure 2(a)). The shoot was $41.4 \%$ of the plant dry matter at this stage. However, the daughter-bulbs and H-bulb combined had already grown to $47.0 \%$ of the plant dry matter. As the plant matured, the shoot lost dry matter and the scales continued to lose dry matter as resources were allocated to the daughter-bulbs and H-bulb. At maturity, the senescing shoot was only $9.8 \%$ of the total dry matter; the daughter-bulbs and H-bulb combined had grown to $86.5 \%$ of the total dry matter; the scales had shrunk to $1.6 \%$ of the total dry matter. (The relative distribution of dry matter and nutrients among the eight organs for five stages of growth shown in Figure 2 is also presented for more accurate quantification in Table S.7 of the Supplementary Materials.)

3.3. Nutrients. Curves for whole plant dry weight and nutrient content are presented in Figures 4(a)-4(f). Each curve was best defined by two connected functions. For all six dependent variables, the best fit for the data was a linear function for the first phase. This was followed by a cubic function ending at senescence for dry matter and total $\mathrm{N}$, $\mathrm{K}, \mathrm{Ca}$, and $\mathrm{Mg}$ content. The initial linear function for total $\mathrm{P}$ content was followed by a second linear function with a steeper positive slope. The join point, as determined by the NLIN program, defines the boundary between the two functions. Although shoot emergence occurred at 94 DAP, the join point for dry weight occurred at $118 \mathrm{DAP}$. Weight loss from respiration continued to exceed photosynthetic weight gain for the period from shoot emergence to 118 DAP, after which, photosynthetic weight gain prevailed.

The linear phase of whole plant nutrient content for N, P, $\mathrm{K}, \mathrm{Ca}$, and $\mathrm{Mg}$ occurred between planting and $84,95,93,94$, and 102 DAP (Figures 4(b)-4(f)). This places the initial point of rapid uptake of $\mathrm{N}, \mathrm{P}, \mathrm{K}, \mathrm{Ca}$, and $\mathrm{Mg}$ at $34,23,25,24$, and 16 days prior to initial weight increase, respectively. Nutrient concentration changes during the initial linear phase were calculated using regression equations from Figure 4 . The N, P, and $\mathrm{Mg}$ contents increased by $7 \%, 14 \%$, and $31 \%$, respectively. In contrast, calcium content increased by $112 \%$. However, dry matter and $\mathrm{K}$ content declined by $24 \%$ and $7 \%$ during this period, respectively. 


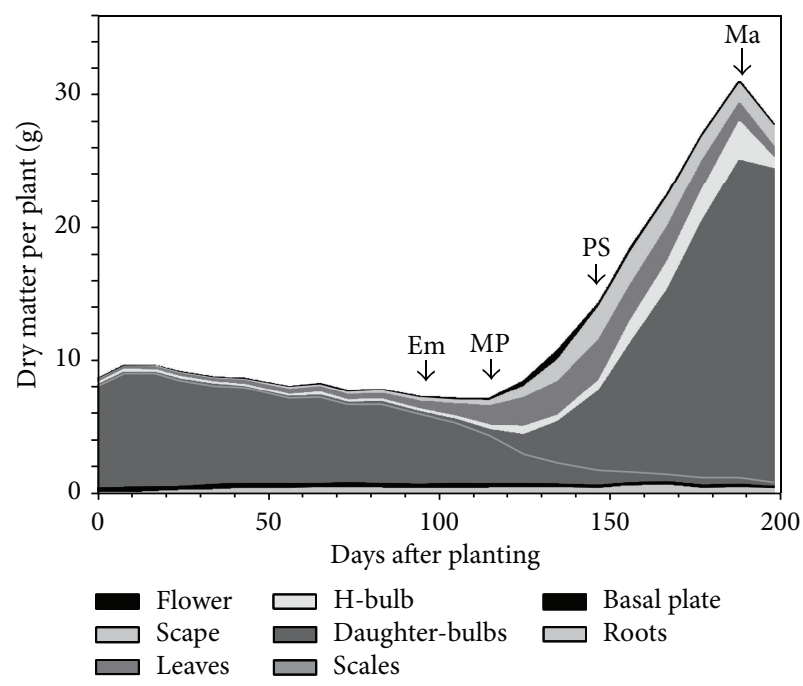

(a)

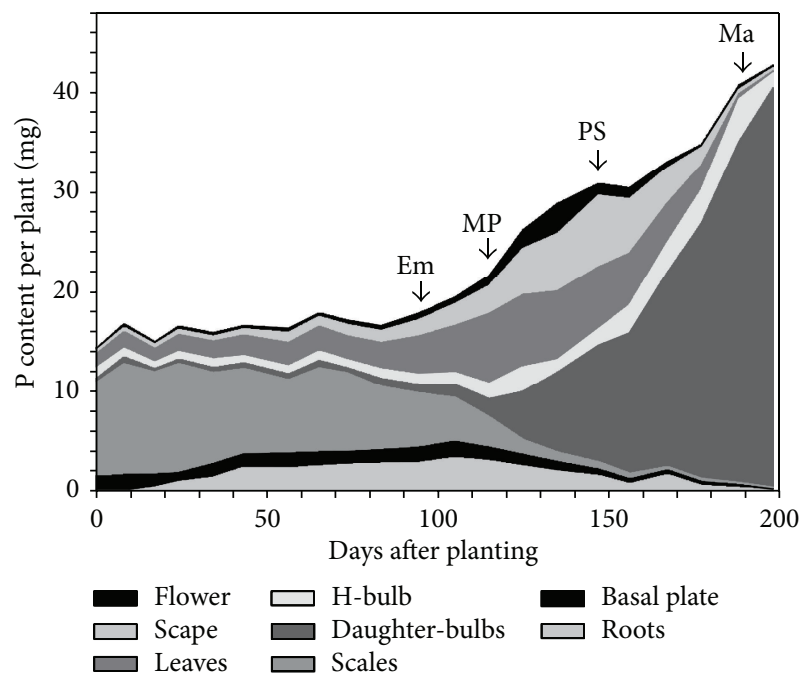

(c)

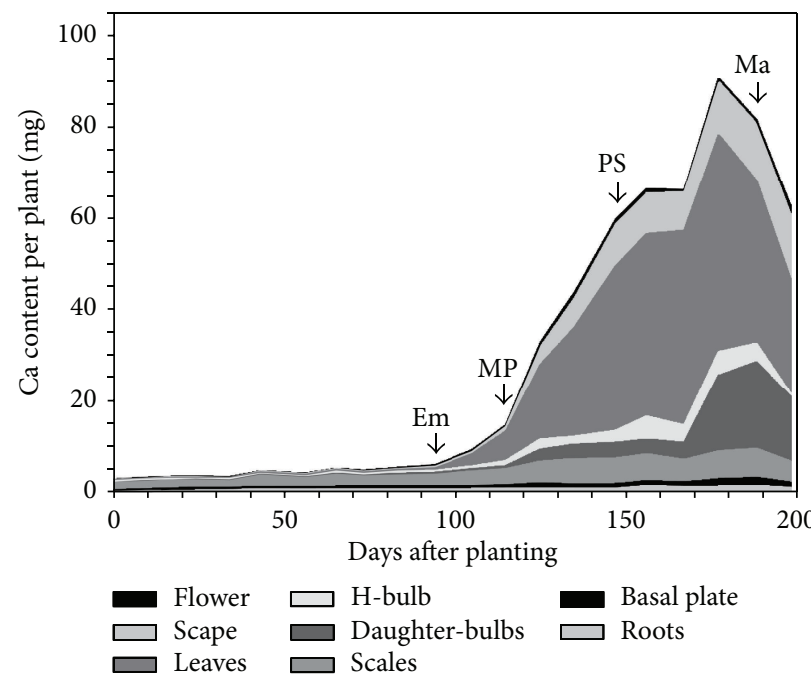

(e)

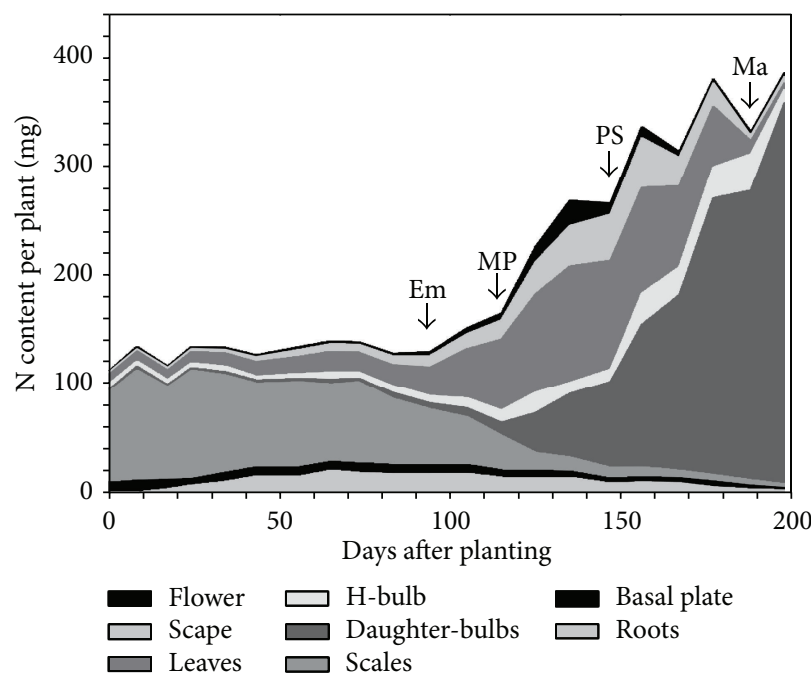

(b)

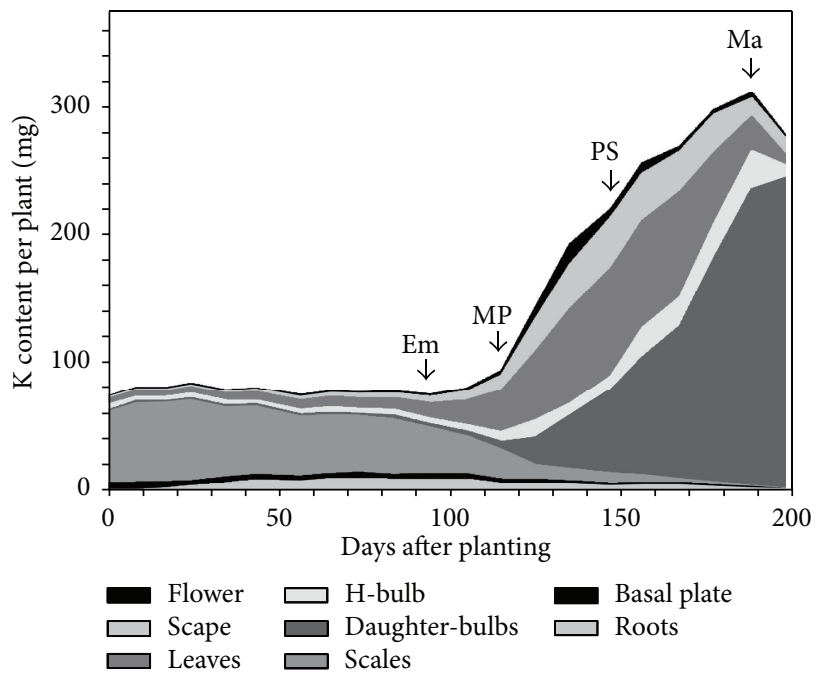

(d)

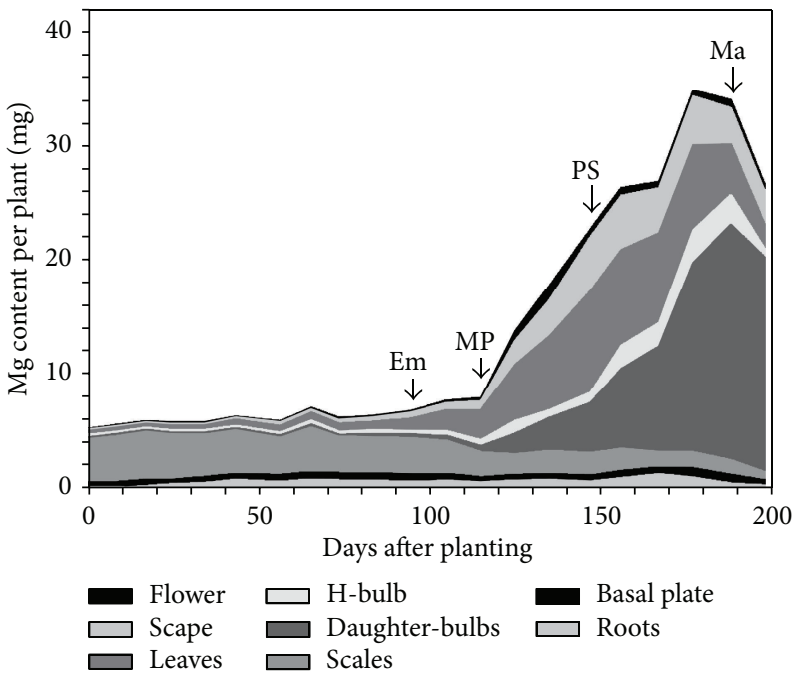

(f)

Figure 2: Profile showing the allocation of dry matter (a), N (b), P (c), K (d), Ca (e), and Mg (f) to organs of T. gesneriana "Paul Richter" during the growing season. Organs appear within each graph in the same order (top to bottom) as listed in the key. Data are plotted additively with vertical distances between lines indicating the quantity of a particular nutrient in each organ. The arrows indicate the dates of shoot emergence (Em), minimum plant (MP) dry matter, peak shoot (PS) dry matter, and bulb maturity (Ma). 


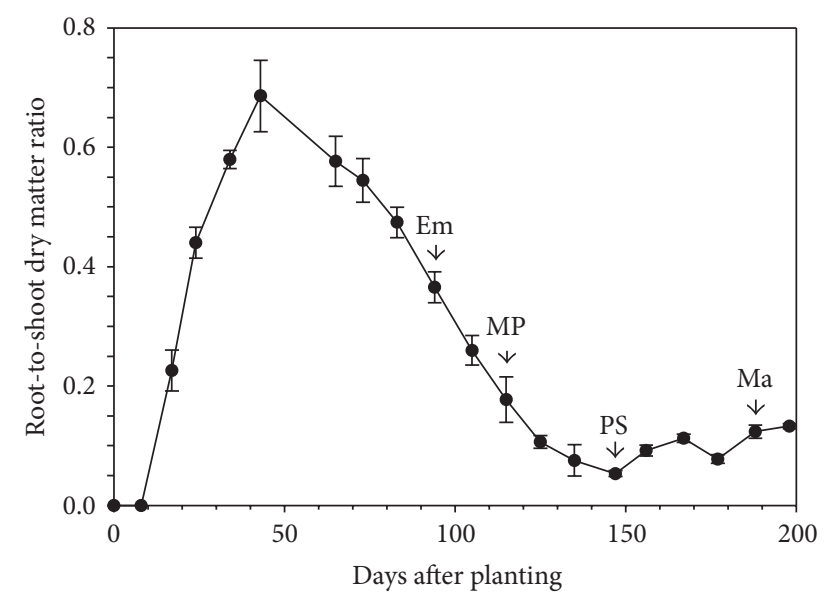

FIGURE 3: Changes in root-to-shoot dry matter ratio from planting to final harvest in T. gesneriana "Paul Richter." The arrows indicate the dates of shoot emergence (Em), minimum plant (MP) dry matter, peak shoot (PS) dry matter, and bulb maturity (Ma).

After the start of the cubic, sigmoidal progression of nutrient accumulation for all nutrients but $\mathrm{P}$, total accumulation closely paralleled the sigmoidal growth curve. The inflection point between increasing and decreasing rates of accumulation in the cubic phase of the curves occurred at approximately $147 \mathrm{DAP}$, the point of peak shoot dry matter. Postmaturity, 188 DAP, decline in dry matter was closely tracked by downward shifts in accumulation of $\mathrm{N}, \mathrm{K}, \mathrm{Ca}$, and $\mathrm{Mg}$. Accumulation of $\mathrm{P}$ differed. It did not decline after maturity but continued to increase up to senescence, 198 DAP.

Scales, being a source of carbon and mineral nutrients for other growing organs, declined in mass and nutrient content throughout the growing season with the exception of $\mathrm{Ca}$ which increased up to the time of maturity.

\section{Discussion}

From the perspectives of commercial production and gardening the annual replacement cycle of the tulip bulb begins with planting of the mother-bulb in the autumn and concludes after flower senescence, about an eight-month period [49]. The bulbs are dug up in early summer. During any given year of the tulip life cycle, originating at planting of the motherbulb and ending with the harvest of the next generation of mother-bulbs, this study shows that the source-sink relationships for mobile nutrient accumulation ( $\mathrm{N}, \mathrm{P}, \mathrm{K}$, and $\mathrm{Mg}$ ) are as follows (Figure 2). From planting to emergence, the scales of the mother-bulb and soil solution are the sources for the sinks that include the shoot (leaves, scape, and plus flowers), daughter-plus $\mathrm{H}$-bulbs, and roots. After emergence, sources include mother-bulb scales, roots, basal plate, and soil solution while the sinks are the daughter- plus H-bulbs, and the shoot up to peak shoot dry matter. After peak shoot dry matter, the shoot becomes a source along with mother-bulb scales, roots, basal plate, and soil solution with the daughterand $\mathrm{H}$-bulbs being the sinks. Translocation of $\mathrm{N}$ from shoot and root to daughter-bulbs in this final stage was likewise reported by Zhou et al. [50].
As in other plants [51], $\mathrm{Ca}^{2+}$ is likewise an immobile nutrient in tulip [52]. They reported that $\mathrm{Ca}^{2+}$ does not translocate from tulip foliage to daughter-bulbs during senescence. The proportionally larger root uptake of $\mathrm{Ca}^{2+}$ prior to shoot emergence compared to other macronutrients was necessitated by the immobility of $\mathrm{Ca}^{2+}$. During this period, concentration of $\mathrm{Ca}^{2+}$ increased in all tissues with the exception of leaves and flowers (Table 1). The source of $\mathrm{Ca}^{2+}$ during this period would be solely root uptake. This was unlike the accumulation of the other macronutrients where the source was a combination of translocation from the scales and root uptake. This is indicated by the decreasing scale content of the other macronutrients contrasted by increasing $\mathrm{Ca}^{2+}$ content in the scales (Figure 2).

It is interesting to examine the driving force for $\mathrm{Ca}^{2+}$ uptake during the preemergence period. Transpiration plays a dominant role in Ca uptake in plants in general $[53,54]$. However, transpiration did not play a role during this period because the shoot had not yet emerged. Growth dilution of $\mathrm{Ca}$ is part of the driving force for uptake [55]. Prior to shoot emergence the shoot, daughter-bulbs, and roots are growing at the expense of stored carbohydrates in the scales, giving rise to new exchange sites in the newly forming cell walls of these organs. Since Ca required for these exchange sites is not transported from the scales, its source becomes the soil. During the preemergence period, the basal plate and scales decreased in dry matter, the H-bulb remained constant, the flower, scape, leaves, and daughter-bulbs increased in dry matter, and roots appeared and grew (Figure 2). Collectively, there was a $143 \%$ increase in dry matter of flower, scape, leaves, daughter-bulbs, and $\mathrm{H}$-bulbs and a $170 \%$ increase in Ca content. These organs accounted for $1.29 \mathrm{mg}$ of the $3.09 \mathrm{mg}$ increase in Ca content of the total bulb. Ca content of developing roots accounted for an additional $0.53 \mathrm{mg}$ of $\mathrm{Ca}$. Uptake of the combined $1.82 \mathrm{mg}$ of Ca can be accounted for by dilution caused by additional growth. The remaining increase of $1.27 \mathrm{mg} \mathrm{Ca}$ that occurred in the basal plate and scales is more difficult to explain. The combined dry matter of these two organs was diminished by $31 \%$ during this period. One possible explanation is consolidation of $\mathrm{Ca}^{2+}$ ion solutes into insoluble $\mathrm{Ca}^{2+}$ compounds such as phosphates, carbonates, and oxalates [55].

During the period from emergence to maturity, whole plant dry matter increased by $302 \%$, while $\mathrm{Ca}^{2+}$ content increased by $1,244 \%$ as calculated using regression equations from Figure 4. This great upsurge in $\mathrm{Ca}^{2+}$ was not surprising since shoot mass increased to $41 \%$ of the plant by peak shoot dry matter (147 DAP). At this point, $78 \%$ of $\mathrm{Ca}^{2+}$ was in the shoot with the largest portion in the leaves $(61 \%)$. This is probably due to the fact that leaf stomata support transpiration, a major driving force for passive $\mathrm{Ca}$ accumulation in plants. Nelson et al. [35] reported a relationship between $\mathrm{Ca}^{2+}$ uptake and transpiration in tulip. Döring [56] reported that the leaves and the perianth (modified leaves) have stomata on both the upper and lower surfaces. In addition, the scape is a green tissue with stomata (Niedziela, personal observation); however, specific Ca uptake is significantly lower in the scape. Concentrations of $\mathrm{Ca}$ at peak shoot formation for the leaves 


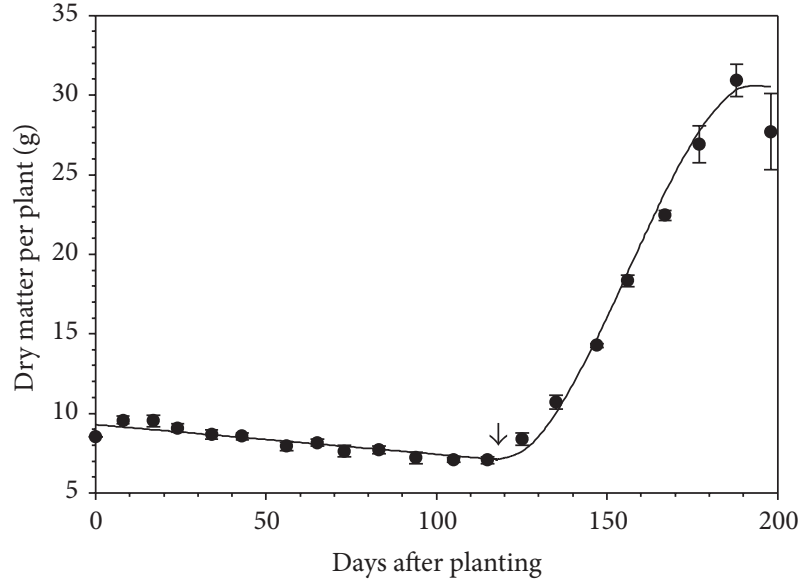

(a)

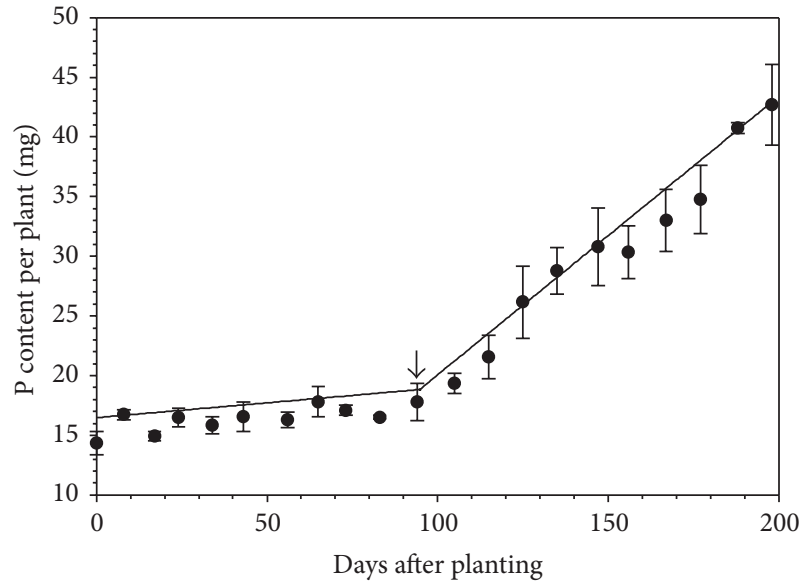

(c)

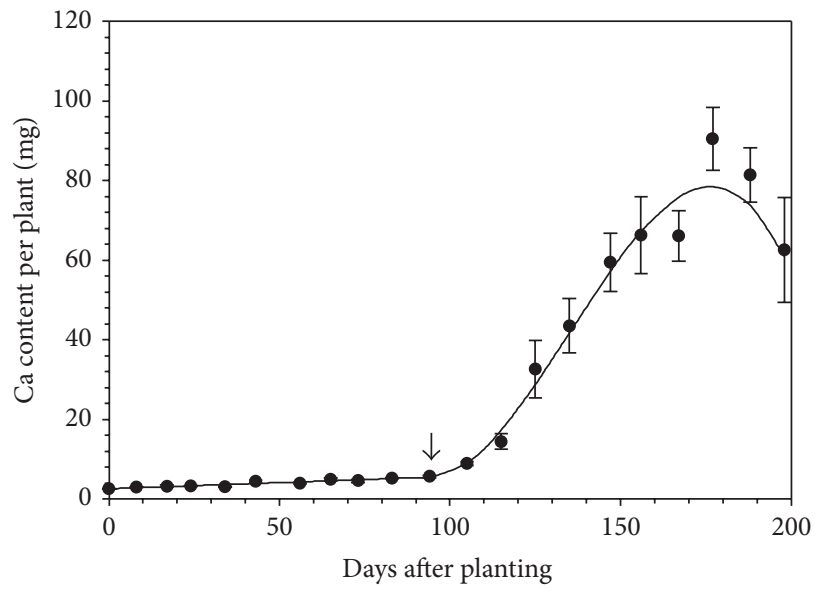

(e)

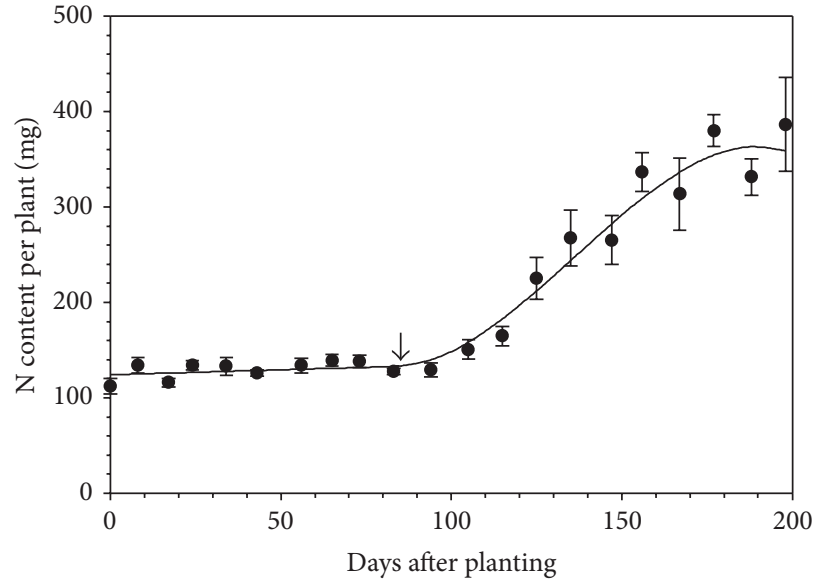

(b)

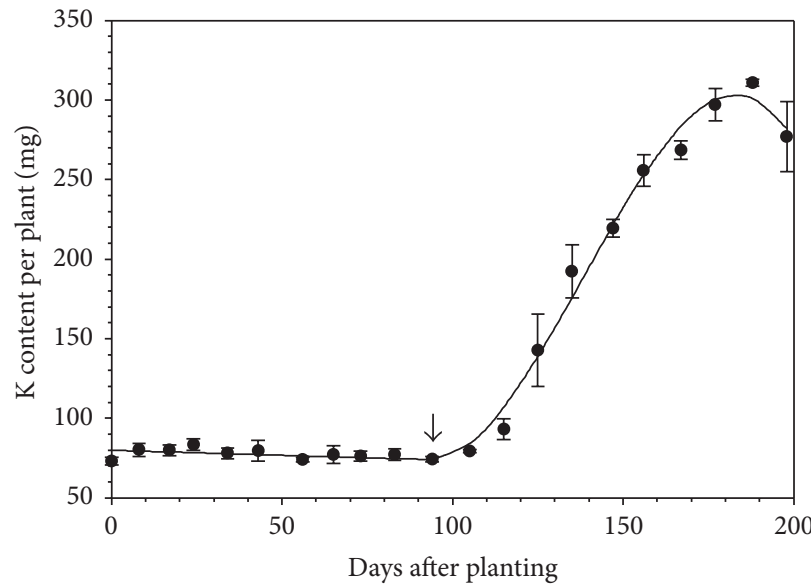

(d)

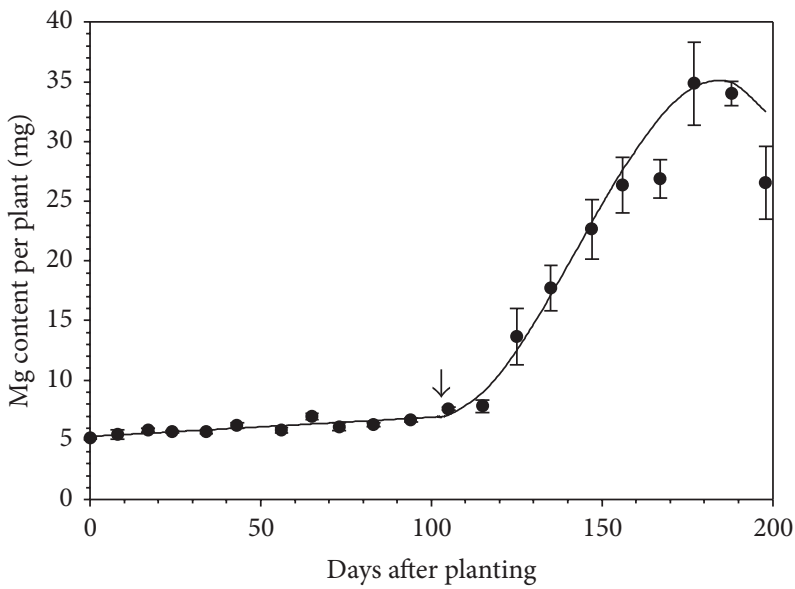

(f)

Figure 4: Changes in total dry matter (a) and $\mathrm{N}(\mathrm{b}), \mathrm{P}(\mathrm{c}), \mathrm{K}(\mathrm{d}), \mathrm{Ca}(\mathrm{e})$, and $\mathrm{Mg}$ (f) content from planting through final harvest in T. gesneriana "Paul Richter" during the growing season. For dry matter, $\mathrm{N}, \mathrm{K}, \mathrm{Ca}$, and $\mathrm{Mg}$, the arrow in each graph indicates the join points for the linear and cubic components of each curve. For P, the arrow in the graph indicates the join point for the two linear components of the curve. The equations for the above curves are as follows. (a) If $x \leq 117.7$, then $y=9.287-0.0186 x$ and if $x>117.7$, then $y=9.287-0.0186 x+0.0127(x-117.7)^{2}-0.00011(x-117.7)^{3}$. (b) If $x \leq 83.88$, then $y=124.2+0.1040 x$ and if $x>83.88$, then $y=124.2+0.1040 x+0.0598(x-83.88)^{2}-0.00038(x-83.88)^{3}$. (c) If $x \leq 94.73$, then $y=16.48+0.0248 x$ and if $x>94.73$, then $y=16.48+0.0248 x+0.2084(x-94.73)$. (d) If $x \leq 93.26$, then $y=79.89-0.0631 x$ and if $x>93.26$, then $y=79.89-0.0631 x$ $+0.0866(x-93.26)^{2}-0.00064(x-93.26)^{3}$. (e) If $x \leq 94.45$, then $y=2.600+0.0308 x$ and if $x>94.45$, then $y=2.600+0.0308 x$ $+0.0318(x-94.45)^{2}-0.00026(x-94.45)^{3}$. (f) If $x \leq 102.1$, then $y=5.291+0.0161 x$ and if $x>102.1$, then $y=5.291+0.0161 x+$ $0.0122(x-102.1)^{2}-0.00010(x-102.1)^{3}$. 


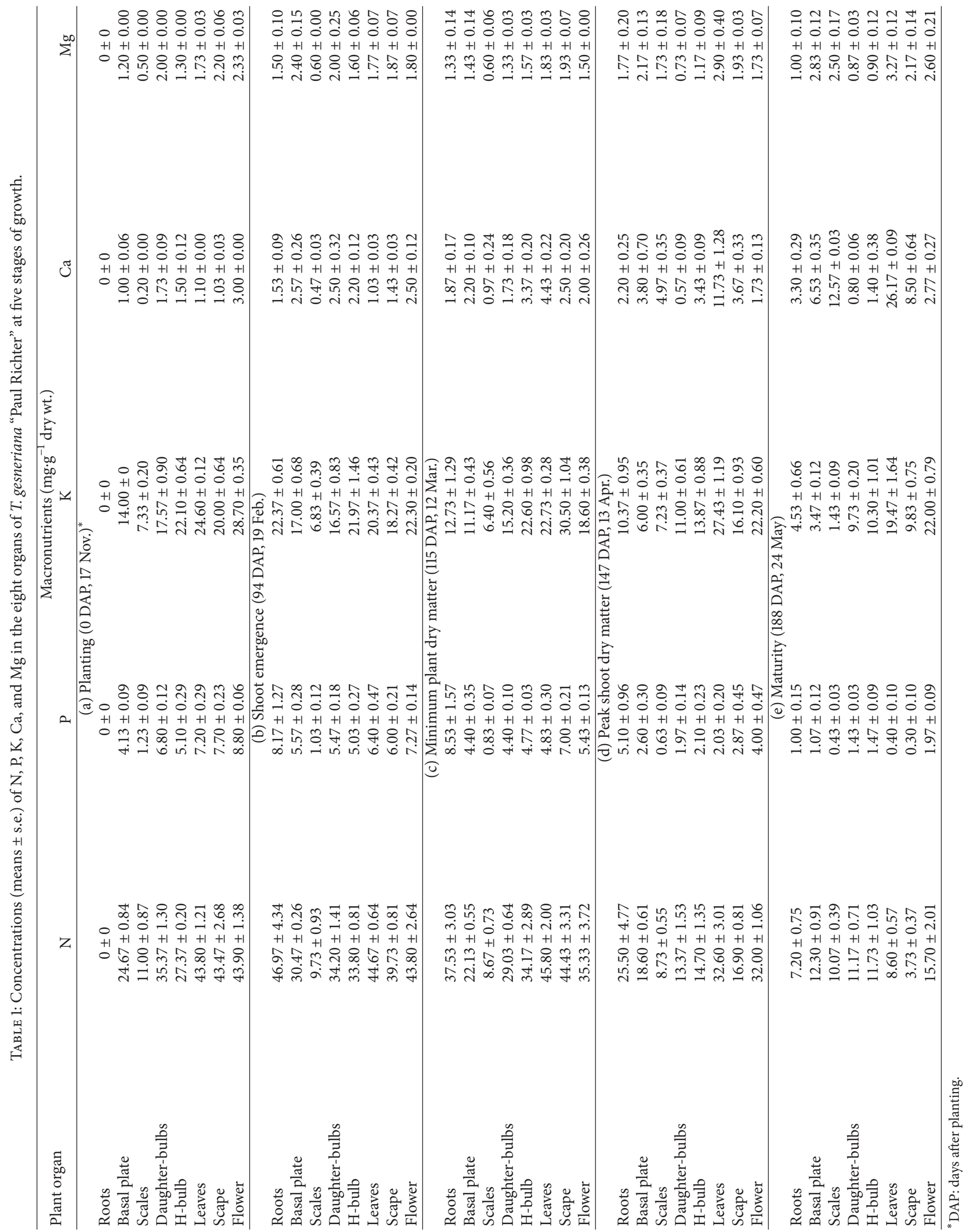


and scape were 11.7 and $3.7 \mathrm{mg} \cdot \mathrm{g}^{-1}$ dry matter, respectively (Table 1). Lower Ca uptake in the scape may be due to the lower specific surface area of the round scape organ as compared to the laminar shaped leaves, the possibility of a lower density of stomata on the scape as compared to leaves, or a combination of these two factors. No references were found concerning the density of stomata on the scape. The tunic and all of the scales of the tulip have stomata, with the exception of the innermost surface of the innermost scale of the tulip [49]. However, scale stomata would contribute little to Ca uptake since these are subterranean organs.

Potassium uptake follows a different pattern than the other nutrients during the initial linear phase of whole plant nutrient content. Potassium decreased by $7 \%$ between planting and join point at $93 \mathrm{DAP}$, while all other nutrients increased during this period. This clarifies the report by van der Boon [19] that there was little response to K fertilization during bulb production, at least prior to emergence in our study. However, the $238 \mathrm{mg}$ uptake of $\mathrm{K}$ per plant after emergence observed in our study, between 93 and 188 DAP (maturity), is in contrast to van der Boon's observation of little need for K fertilization. Ramírez-Martínez et al. [57] reported there is heavy partitioning of $\mathrm{K}$ into newly forming bulbs. This indicates a significant postemergence requirement for $\mathrm{K}$. The implication from a low $\mathrm{K}$ fertilization response coupled with a sizeable $\mathrm{K}$ bulb requirement is that the tulip plant is a very efficient accumulator of $\mathrm{K}$. This suggests a low $C_{\min }$ value, the bathing solution concentration where influx of a given nutrient equals efflux. A low $C_{\min }$ value enables the plant to achieve a net $\mathrm{K}$ uptake at soil solution concentrations supported by mineralization of soil minerals and organic matter. Claassen and Jungk [58] reported average $\mathrm{K}$ soil solution $C_{\min }$ values of $2-3 \mu \mathrm{mol} \cdot \mathrm{L}^{-1}$ for soilgrown plants, while Caassen and Barber [59] reported $\mathrm{K}$ $C_{\text {min }}$ values of $1-2 \mu \mathrm{mol} \cdot \mathrm{L}^{-1}$ for young corn plants. The low requirement for $\mathrm{K}$ fertilization is further supported by the low sufficiency concentration value of 0.1 to $0.5 \% \mathrm{~K}$ in bulbs at harvest reported by Hansen [16] and Tissot [24]. There are strong implications from these results relative to fertilization practices for the tulip. The main one is that $\mathrm{K}$ fertilization is not needed at planting and only a moderate application is beneficial at emergence.

It is noteworthy that the join points in the graphs for accumulation of all five nutrients preceded the join point for biomass accumulation by 16 to 34 days (Figure 4). This indicates that nutrient accumulation could be an effective parameter for modeling growth in tulip. This would be particularly true for $\mathrm{N}$ since the join point for $\mathrm{N}$ accumulation preceded net dry matter accumulation by 34 days, the longest period for any nutrient (Figure 4).

\section{Conclusions}

Moderate uptake of $\mathrm{N}, \mathrm{P}, \mathrm{Ca}$, and $\mathrm{Mg}$ by tulips occurred from root appearance until near shoot emergence from the soil, while K content decreased slightly. During this period, relative uptake of Ca was considerably higher than that of the other nutrients. A substantial increase in uptake began prior to shoot emergence for $\mathrm{N}$; at about the same time as shoot emergence for $\mathrm{P}, \mathrm{K}$, and $\mathrm{Ca}$; and following shoot emergence for Mg. All of these upsurges preceded a similar rise in dry matter. Since the transition (join point) from the initial to the accelerated uptake phases of $\mathrm{N}, \mathrm{P}, \mathrm{K}, \mathrm{Ca}$, and $\mathrm{Mg}$ occurred prior to initial dry matter increase, the accumulation of these nutrients ( $\mathrm{N}$ in particular) could be used to predict changes in tulip plant growth.

Major sources for dry matter and nutrients throughout the entire annual bulb replacement cycle included scales (dry matter and nutrients), soil solution (nutrients), and photosynthesis in shoots (dry matter). Shoots as well as roots (dry matter and nutrients) became sources after their senescence. Major sinks for dry matter and nutrients consisted of daughter- plus H-bulbs throughout the cycle, shoots up to peak shoot dry matter (147 DAP), and roots up to bulb maturity (167 DAP).

There are also practical fertilization applications from this study. Although some $\mathrm{N}, \mathrm{P}$, and $\mathrm{Mg}$ were taken up prior to emergence, the bulk of the uptake occurred after emergence. These data suggest applying these nutrients as a split application with a smaller application at planting and a larger application at or shortly after emergence. Since there was a decline in $\mathrm{K}$ content up to emergence with net uptake restricted to postemergence, a $\mathrm{K}$ fertilizer could be applied only at or shortly after emergence. Calcium was taken up throughout the experiment emphasizing the need to maintain optimum soil levels through application of lime for $\mathrm{pH}$ maintenance.

\section{Disclaimer}

The use of trade names in this publication does not imply endorsement by the North Carolina Agricultural Research Service of the products named, nor criticism of similar ones not mentioned.

\section{Conflict of Interests}

The authors declare that there is no conflict of interests regarding the publication of this paper.

\section{Acknowledgments}

This work was supported by the Dutch Bulb Exporters Association, Hillegom, the Netherlands, and the North Carolina Agricultural Research Service (NCARS), Raleigh, NC, USA. Appreciation is expressed to August De Hertogh and Marcel Le Nard for their critical review of this paper and Joy Smith for her assistance with the statistical analysis.

\section{References}

[1] M. Le Nard and A. A. De Hertogh, "Tulipa," in The Physiology of Flower Bulbs, A. A. De Hertogh and M. Le Nard, Eds., pp. 617-682, Elsevier, New York, NY, USA, 1993.

[2] A. R. Rees, The Growth of Bulbs: Applied Aspects of the Physiology of Ornamental Bulbous Crop Plants, vol. 1 of Applied Botany Series, Academic Press, New York, NY, USA, 1972. 
[3] A. R. Rees, Ornamental Bulbs, Corms and Tubers, vol. 1 of Crop Production Science in Horticulture, CAB International, Wallingford, UK, 1992.

[4] A. A. De Hertogh, L. H. Aung, and M. Benschop, "The tulip: botany, usage, growth, and development," in Horticulture Reviews, vol. 5, pp. 45-125, 1983.

[5] A. M. Hartsema, "Influence of temperatures on flower formation and flowering of bulbous and tuberous plants," in The Encyclopedia of Plant Physiology, W. Ruhland, Ed., vol. 16, pp. 123-167, Springer, Berlin, Germany, 1961.

[6] E. J. Fortanier, "Reviewing the length of the generation period and its shortening, particularly in tulips," Scientia Horticulturae, vol. 1, no. 1, pp. 107-116, 1973.

[7] J. M. Gilford and A. R. Rees, "The tulip shoot apex. I. Structure and development," Scientia Horticulturae, vol. 2, no. 1, pp. 1-10, 1974.

[8] J. M. Gilford and A. R. Rees, "The tulip shoot apex. II. Growth," Scientia Horticulturae, vol. 2, no. 1, pp. 11-20, 1974.

[9] P. Artacho-Vargas and D. Pinochet-Tejos, "Dry matter yield and nitrogen uptake of tulip (Tulipa gesneriana L.) plants," Agrociencia, vol. 42, no. 1, pp. 37-45, 2008.

[10] W. J. De Munk, P. Hoogeterp, and G. Slootweg, "Effects of nitrogen dressing on flower-bud blasting in tulips during forcing," Acta Horticulturae, vol. 109, pp. 81-87, 1980.

[11] D. P. J. Mulder, "Stikstofbemesting in de bloembollenteelt," Mededeeling Director Tuinbouw, vol. 19, pp. 706-715, 1956.

[12] L. Algera, "Over de opname van voedingsstoffen uit den bodem door de tulip," Landbouw Tijdschrift, vol. 56, pp. 432-438, 1944.

[13] H. Benkenstein, H. Nehl, H. Pesche, and P. Richter, "Zur Stichstoffdüngung von Tulpen. 2. Mitteilung: Einfluss des Zeitpunktes der Stickstoffgabe," Archiv Gartenbauwissenschaft, vol. 26, pp. 323-332, 1978.

[14] T. Ohyama, T. Ikarashi, and A. Baba, "Nitrogen accumulation in the roots of tulip plants (Tulipa gesneriana)," Soil Science and Plant Nutrition, vol. 31, pp. 581-588, 1985.

[15] T. Ohyama, T. Ikarashi, A. Obata, and A. Baba, "Role of nitrogen accumulated in tulip roots during winter season," Soil Science and Plant Nutrition, vol. 34, no. 3, pp. 341-350, 1988.

[16] H. Hansen, "Studies on the growth pattern of tulip," Tidsskrift för Planteavl, vol. 80, pp. 869-892, 1976.

[17] E. Skalska, "Etude de la nutrition des tulipes par la méthode des analyses de plantes," in Colloque européen sur le contrôle de la nutrition minérale et la fertilization, Institut Agronomique Méditerranéen, Montpellier, France, 1964.

[18] K. Hagiya and W. Amaki, "Nutritional studies on tulips. III. Seasonal changes in three major elements in water," Journal of the Japanese Society for Horticultural Science, vol. 35, pp. 170$176,1966$.

[19] J. van der Boon, "Tijdstip van stikstofopname door de tulip," Stikstof, vol. 6, pp. 459-465, 1972.

[20] T. Tsutsui, "Nitrogen fertilization in tulip bulb production in Japan," Acta Horticulturae, vol. 47, pp. 347-352, 1975.

[21] W. F. Cheal and G. W. Winsor, "The effects of nitrogen, phosphorus, potassium and magnesium on the growth of tulips during the second season of treatment and on the chemical composition of the bulbs," Annals of Applied Biology, vol. 57, no. 2, pp. 287-299, 1966.

[22] W. F. Cheal and G. W. Winsor, "The residual effect of previous nutritional treatments on the growth and composition of tulips supplied with complete nutrients in sand culture," Annals of Applied Biology, vol. 57, no. 3, pp. 379-388, 1966.
[23] W. Amaki and K. Hagiya, "Studies on fertilizer supply to tulips. 1. The effects of varied amounts of three nutrient elements on the growth of plants and the yield of bulbs," Japanese Horticulture Association, vol. 29, pp. 157-162, 1969.

[24] R. E. Tissot, Fertilization of Tulipa gesneriana 'Paul Richter' during forcing and field culture [M.S. thesis], North Carolina State University, Raleigh, NC, USA, 1980.

[25] E. J. Hewitt and P. Miles, "The effects of deficiencies and excesses of some mineral nutrients on the growth tulip and daffodil bulbs in sand culture," Journal of Horticultural Science, vol. 29, pp. 237244, 1954.

[26] C. F. Cheal and G. W. Winsor, "Response of tulips ('Elmus') to nitrogen and potassium. Part II. Field-grown crops," Experimental Horticulture, vol. 19, pp. 61-77, 1969.

[27] L. Algera, "Topple disease of tulips," Journal of Phytopathology, vol. 62, no. 3, pp. 251-261, 1968.

[28] P. Hoogeterp, "Kiepen van tulpen vaar veroorzaakt door cultuurfouten," Vakblad voor de Bloemisterij, vol. 37, pp. 40-41, 1979.

[29] T. Igarashi, M. Yoshida, and A. Baba, "The relationship between liming and 'Kubioremagari' (topple) or 'Kubiore' and 'Ironuke' in tulip plant on dune field," Bulletin of the Faculty of Agriculture, Niigata University, vol. 33, pp. 9-21, 1981.

[30] A. Klougart, "Calcium uptake of tulips during forcing," Acta Horticulturae, vol. 109, pp. 89-95, 1980.

[31] F. Penningsfeld and F. Kalthoff, Blutenentwicklung von lumenzwiebeln bei unterschiedlicher Bodemreaktion und Dungungshohe, Sonderdruck aus dem Jahresbericht 1975 der Fachhochschule Weihenstephan, Inststitut fur Bodenkunde und Pflanzenernahrung, 1975.

[32] J. van der Boon, Het trekken van tulpen op veen; de noodzakelijke bekalking, Bedrijfsontwikkeling, jaargang, vol. 5, Instituut voor Bodemvruchtbaarheid, Haren-Groningen, The Netherlands, 1974.

[33] P. V. Nelson and C. E. Niedziela Jr., "Effects of calcium source and temperature regime on calcium deficiency during hydroponic forcing of tulip," Scientia Horticulturae, vol. 73, no. 2-3, pp. 137-150, 1998.

[34] P. V. Nelson and C. E. Niedziela Jr., "Effect of ancymidol in combination with temperature regime, calcium nitrate, and cultivar selection on calcium deficiency symptoms during hydroponic forcing of tulip," Scientia Horticulturae, vol. 74, no. 3, pp. 207-218, 1998.

[35] P. V. Nelson, W. Kowalczyk, C. E. Niedziela Jr., N. C. Mingis, and W. H. Swallow, "Effects of relative humidity, calcium supply, and forcing season on tulip calcium status during hydroponic forcing," Scientia Horticulturae, vol. 98, no. 4, pp. 409-422, 2003.

[36] Anonymous, "Magnesiumgebrek," Bloembollencontact, vol. 2, p. $15,1980$.

[37] A. Mügge and P. Richter, "Mikronahrstoffdüngung im Tulpenvermehrungsanbau," Archiv für Gartenbauwissenschaft, vol. 27, pp. 246-247, 1980.

[38] M. Bakker, Teelt Information, vol. 9, CNB Information, Lisse, The Netherlands, 1991.

[39] F. U. Khan, A. Q. Jhon, F. A. Khan, and M. M. Mir, "Effect of NPK and $\mathrm{Zn}$ on growth, flowering and bulb production in tulip under polyhouse conditions in Kashmir," Journal of Horticultural Sciences, vol. 1, pp. 129-134, 2006.

[40] P. J. Hocking, "Accumulation, partitioning and redistribution of dry matter and mineral nutrients Ixia flexuosa L., with special reference to its cormaceous habit," Annals of Botany, vol. 53, no. 4, pp. 489-501, 1984. 
[41] P. J. Hocking, "Seasonal dynamics of the accumulation, distribution and redistribution of dry matter and mineral nutrients in a weedy species of gladiolus (Gladiolus caryophyllaceus)," Annals of Botany, vol. 71, no. 6, pp. 495-509, 1993.

[42] C. Ruiters and B. McKenzie, "Seasonal allocation and efficiency patterns of biomass and resources in the perennial geophyte Sparaxis grandiflora subspecies fimbriata (Iridaceae) in lowland coastal fynbos, South Africa," Annals of Botany, vol. 74, no. 6, pp. 633-646, 1994.

[43] Z. C. Somda, W. J. McLaurin, and S. J. Kays, "Jerusalem artichoke growth, development, and field storage. II. Carbon and nutrient element allocation and redistribution," Journal of Plant Nutrition, vol. 22, no. 8, pp. 1315-1334, 1999.

[44] S. Al-Tardeh, T. Sawidis, B.-E. Diannelidis, and S. Delivopoulos, "Water content and reserve allocation patterns within the bulb of the perennial geophyte red squill (Liliaceae) in relation to the Mediterranean climate," Botany, vol. 86, no. 3, pp. 291-299, 2008.

[45] N. K. Subramanian, P. J. White, M. R. Broadley, and G. Ramsay, "The three-dimensional distribution of minerals in potato tubers," Annals of Botany, vol. 107, no. 4, pp. 681-691, 2011.

[46] A. Fleck and J. Davidson, "Micro determination of nitrogen," Critical Reviews in Analytical Chemistry, vol. 4, no. 2, pp. 141154, 1974.

[47] H. D. Chapman and P. F. Pratt, Methods of Analysis for Soils, Plants, and Waters, Division of Agricultural Science, University of California, Berkeley, Calif, USA, 1961.

[48] A. R. Gallant and W. A. Fuller, "Fitting Segmented Polynomial Regression Models Whose Join Points Have to Be Estimated," Journal of the American Statistical Association, vol. 68, no. 341, pp. 144-147, 1973.

[49] A. A. De Hertogh and M. Le Nard, "Physiological and biochemical aspects of flower bulbs," in The Physiology of Flower Bulbs, A. A. De Hertogh and M. Le Nard, Eds., pp. 617-682, Elsevier, New York, NY, USA, 1993.

[50] P.-S. Zhou, B. Pei, Y.-M. Shi, and X.-P. Ma, "Study on the accumulation \& distribution of nutrition on 15N-labeled tulips," Journal of Shanghai Jiaotong University-Agricultural Science, vol. 21, pp. 309-312, 2003.

[51] L. Taiz and E. Zeiger, Plant Physiology, Sinauer Associates Inc, Sunderland, Mass, USA, 3rd edition, 2002.

[52] H. W. Schmalfeld and R. I. Carolus, "Nutrient redistribution in tulip," Proceeding of the American Society for Horticultural Science, vol. 86, pp. 701-707, 1965.

[53] N. Lazaroff and M. G. Pitman, "Calcium and magnesium uptake by barley seedlings," Australian Journal of Biological Sciences, vol. 19, pp. 991-1005, 1966.

[54] G. Michael and H. Marschner, "Influence of varied air humidity and transpiration on mineral uptake and distribution," Zeitschrift für Pflanzenernährung, Düngung, Bodenkunde, vol. 96, pp. 200-212, 1962.

[55] K. Mengel and E. A. Kirkby, Principles of Plant Nutrition, International Potash Institute, Bern, Switzerland, 4th edition, 1987.

[56] E. Döring, Das Leben der Tulpe, Druck und Verlag von Paul Oertel, Sonderhausen, Germany, 1910.

[57] M. Ramírez-Martínez, L. Trejo-Téllez, F. Gómez-Merino, P. Sánchez-García, M. N. Rodríguez-Mendoza, and M. SandovalVilla, "Potassium/calcium ratios of the nutrient solution on tulip nutrient status," Acta Horticulturae, vol. 843, pp. 119-122, 2009.
[58] N. Claassen and A. Jungk, "Kaliumdynamik im wurzelnahen Boden in Beziehung zur Kaliumaufnahme von Maispflanzen," Zeitschrift für Pflanzenernährung und Bodenkunde, vol. 145, no. 6, pp. 513-525, 1982.

[59] N. Caassen and S. A. Barber, "Simulation model for nutrient uptake from soil by a growing plant root system," Agronomy Journal, vol. 68, no. 6, pp. 961-964, 1976. 


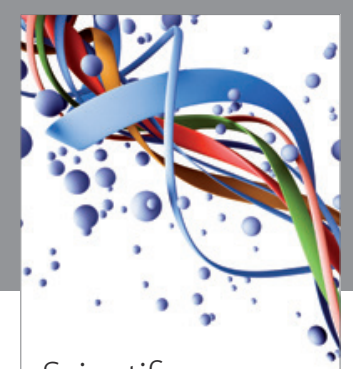

Scientifica
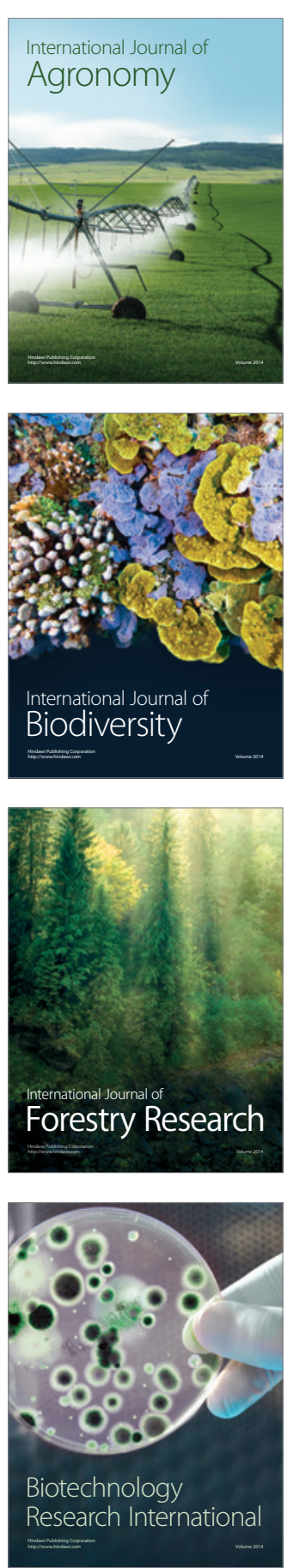
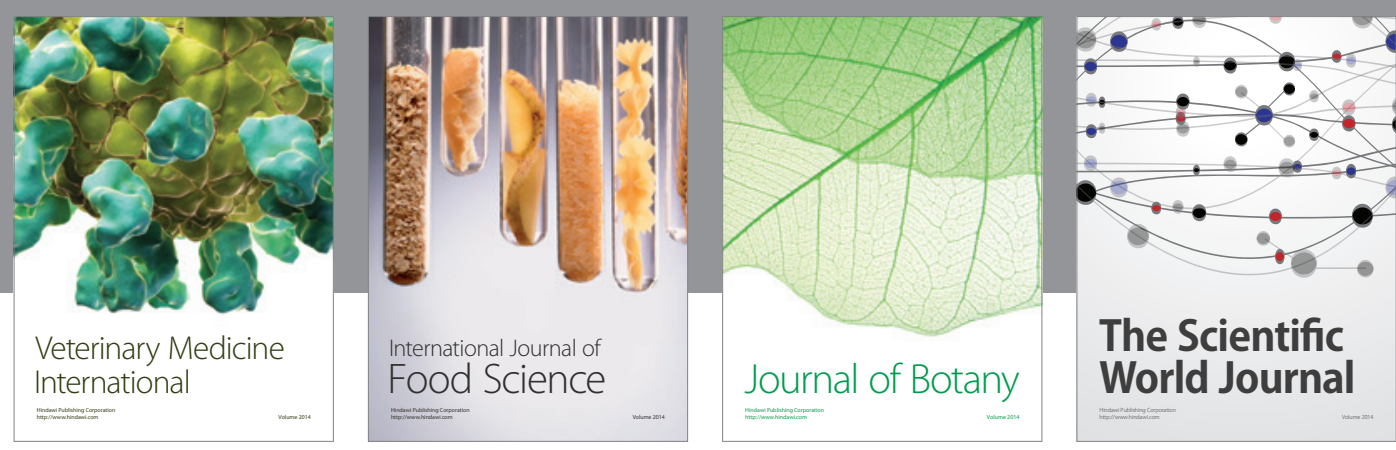

The Scientific World Journal
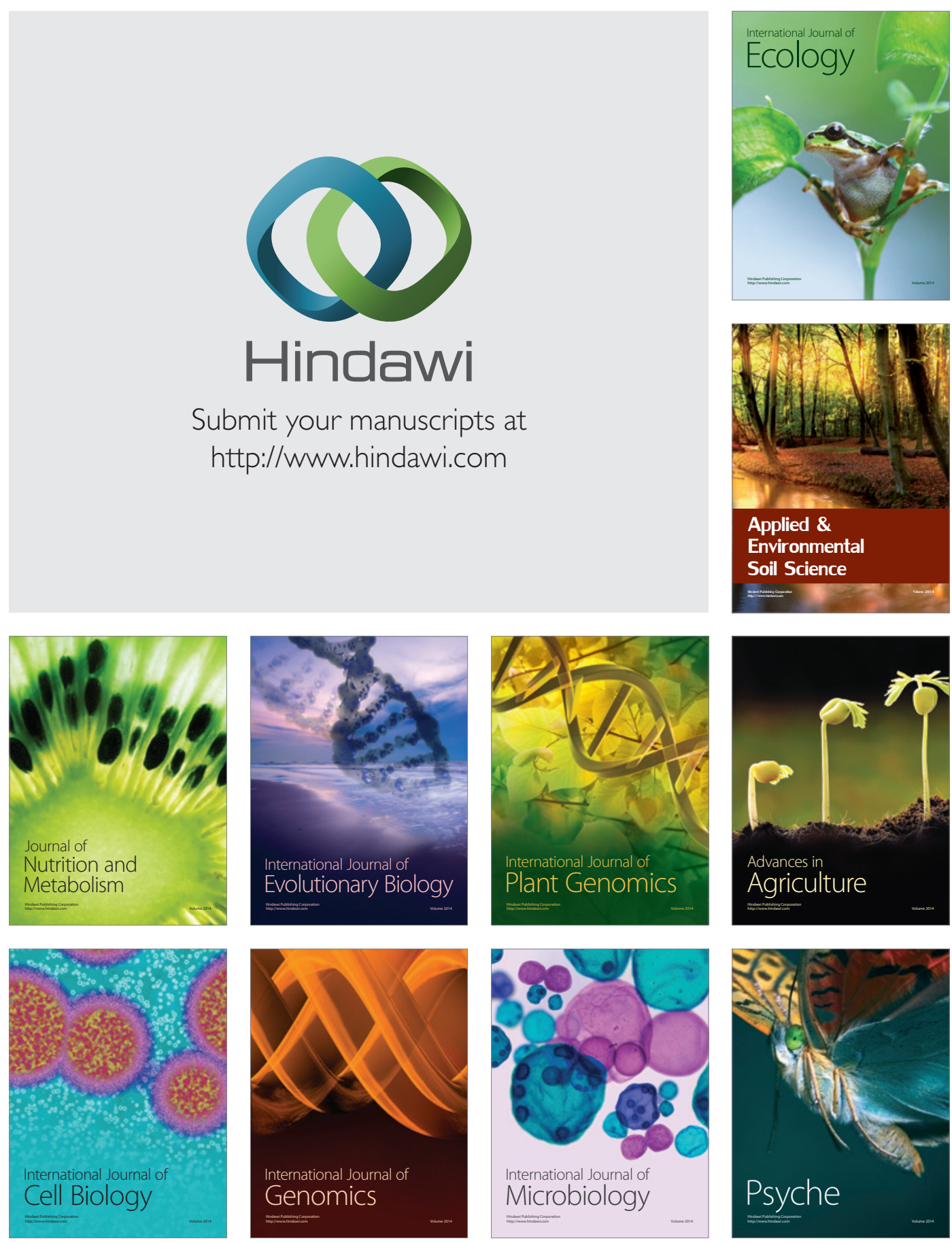